\title{
The Intertwining of History and Heritage in Islamic Contexts
}

\section{Shabzad Bashir}

\begin{abstract}
This chapter argues that Islamic history should be imagined as an ever-expanding web of overlapping and competing discourses about the past. Islam's transhistorical presence is an illusion that is borne of the historiographical process. Clusters of evidence we can identify pertaining to Islam are traceable to moments with their own distinctive senses of past, present, and future. Consequently, what is to be regarded as Islamic heritage depends fundamentally on the frame within which it was produced. Moreover, scholarly appreciation of heritage is itself a value-laden enterprise that participates in the creation of Islamic meanings. I advocate that we pay utmost attention to the particularities of the Islamic evidence we encounter, while simultaneously avoiding reification and being mindful of our own interpretive commitments.
\end{abstract}

Keywords Islamic history $\cdot$ historiography $\cdot$ Iran $\cdot$ Isfahan

During a journey for the hajj from his home in northwestern Iran, the poet Afzal al-Din Khaqani (d. ca. 1186-1199) is said to have made a stop at Mada'in (Greek: Ctesiphon), the ruined capital of the pre-Islamic Sasanian

S. Bashir $(\bowtie)$

Brown University, Providence, RI, USA

(C) The Author(s) 2017

T. Rico (ed.), The Making of Islamic Heritage, Heritage Studies in the

Muslim World, DOI 10.1007/978-981-10-4071-9_2 
dynasty. The visit is said to have inspired him to write a celebrated ode (qasida) that begins as follows:

Beware, $\mathrm{O}$ heart that sees portents, look with insight, consider Mada'in's great arch the admonishing mirror. Leaving the banks of the Tigris, alight at Mada'in, on its ground let spill from your eyes, another Tigris (Khaqani 1996, 162).

These verses encapsulate a relationship between past evidence and present concern that is central to discourses about heritage. Khaqani commences by commanding the listener to look at the old palace's arch, a monumental structure that still stands and is emblematic of the glories of ancient Persian empires (Bruno 1966). By the poet's guidance, the visual observation turns the ruined arch into an omen. The remains, crumbling yet magnificent, come to stand for the ravages of time. Having seen, the eye turns to a different function, shedding tears in imitation of the flow of the nearby river Tigris that once allowed Mada'in to be a thriving inhabitation. Goaded by the evidence of the dead concretized in the arch, the observing person's actions and emotions attend to mortality and other existential issues pertaining to human life. ${ }^{1}$

Khaqani's poetic musing on the Sasanian arch is the product of a bygone era's moral sensibilities and literary conventions. But his command to consider the pedagogical potential of traces of past lives has much in common with publicity materials produced by modern caretakers of archeological sites and museums. Signage, brochures, and guided tours at such locations invite visitors to observe old objects and imagine lives associated with them before they were removed from ordinary usage. In a larger frame, societal investment in preserving traces of certain pasts connects to intellectual and sociopolitical interests of those endowed with resources. Expressions such as that of Khaqani can be found in many, if not all, sociohistorical contexts. There is, then, something universal about cycling through past material to ruminate on the present. But what is to be considered valuable in this regard-what preserved or displayed and what destroyed or hidden-varies greatly between situations. The past is manufactured by linking evidence and contextualization, both elements being open to interpretation and manipulation.

The question of heritage-which I define as the past that is deemed valuable in a given situation-has been woven into discussions of Islam since the religion's inception. Details of the life of the Prophet 
Muhammad are central to Islamic discourses about practice as well as thought, and the history of Islam's origins has been a contested field from the earliest recorded discussions. This issue extends to former and later periods too since Islamic self-understandings include, first, preIslamic biblical and other Near Eastern narratives about the past, and second, historical contingencies of events occurring in many regions between the sixth-century CE and the present. Disagreement over facts and interpretations has been endemic to all historical conclusions made with respect to Islam. All this diversity notwithstanding, modern academic representations have, up to our own present, tended to flatten the matter into a single timeline that runs from Muhammad to now (Bashir 2014).

For purposes of heritage studies, I suggest that Islamic history is best imagined as a dynamic process rather than a settled narrative. I recommend this on the basis of textual materials, an abundant and influential resource for thinking about Islam as a historical phenomenon. Islamic texts that pertain to history signify in double: They are elements within material culture in the same sense as buildings and archeological sites, and they contain discourses pertaining to the lives and thoughts of Muslims that have the past as a major component. The first element relates to paleography and related fields, a domain that lies beyond my current discussion. I am concerned with narrative representation of past time as a key ingredient within textual production pertaining to Islam. I believe this to be an arena marked by variety and continual evolution rather than constancy. In the manner of Khaqani urging his listener to look and be moved by the arch of Madain, Islamic discourses engage evidence from pasts to create meanings in presents. What things deserve observation, and what lessons one is to draw from these, can vary radically between different Islamic contexts. A historicizing look at textual representations of the past provides us resources to consider material culture in all its complexity.

\section{Islam's Multiple Pasts}

In customary modern academic practice, representations of the past that invoke Islamic themes are assessed by judging their plausibility in terms that make sense to us. Could an event have occurred as it is described, given corroborating or contradictory evidence? Are the details a logical possibility given our understanding of causality? For example, we can take the report about a person's date of death to be a fact while a miracle in which God is said to have intervened on the side of one party is likely to be 
discounted as rhetoric or religious belief. Through such judgments, we cull information from Islamic sources to create historiographical narratives that are viable in our own context. This approach, endemic to the modern academic field of Islamic history, has the drawback that it renders most of the contents of the original sources meaningless. These works simply do not share fully in the realist and literary conventions we take for granted. Moreover, reading in this way absolves us from reflecting on our own unstated presumptions about the past.

Counter to the existing dominant paradigm, I believe we should regard Islamic narratives about the past as rhetorical exercises that suture received information to the concerns of the present times in which they were produced. This is to say that we begin by acknowledging that writings in genres that pertain to the past (chronicles, hagiography, prosopography, etc.) depend on internal rules about evidence and are not to be treated as fiction. However, such works amalgamate information and interpretation to the point of inseparability. Rather than making ad hoc judgments about what is possible and what false, we should regard the narratives in the manner of looking at a building. The words and concepts that constitute them are like common construction materials, but the forms in which we find them are distinctive instantiations that reflect the world of the people who undertook their creation.

What we make of "Islam" holds a particularly important place when considering descriptions of the past in this way. Islam represents a commonality between narratives originating in different contexts as, for instance, we can pick one author from the ninth century and another from the nineteenth and observe that both refer to Islam as a cornerstone of their understandings of heritage, the valuable past. The usual way to interpret this commonality would be that the two authors are talking about the same phenomenon. Islam then comes to be understood as a suprahistorical entity that stands apart from the authors and is a universal reference point for both of them. This view makes excellent sense from the perspective of religious thought since it ratifies the sense of continuity that is necessary for the self-understanding of a tradition. But such an interpretation is historiographically problematic and needs a thorough reversal. I believe it is more appropriate to think that the putative two authors are "creating" Islam and are referring to quite different phenomena even as they use the same word. Historically speaking, Islam is an aspect of imagination and cannot exist beyond its particular constructions, which we know to differ greatly between different contexts. Islam's transhistorical presence 
is an illusion that is born of the historiographical process. In order to understand trajectories of Islamic thought, we certainly need to be cognizant of the fact that many people invoke Islam as a universal. But when working in a historicist mode, it is problematic to take the claim of continuity on face value.

The view I am proposing necessitates that we regard the history of Islam as a story riven with fissures and fractures rather than smooth chronological development along an arc that can be plotted. To take this route has repercussions for multiple aspects of the consideration of temporality. It means that synchronically - that is, at any "present" momentwe must expect understandings of the past involving Islam to be contested between different options. "History" in this instance would have to include the story of these contestations rather than a conglomeration of facts that can be established outside the frames of the narratives we possess. Furthermore, the options we may be able to identify as possibilities at a given moment must be presumed to have diachronic dimensions, indicating evolution of strands of thought in conjunction with sociohistorical contingencies. Yet further, we have to allow for the fact that entirely new interpretations can come into being and that neither the synchronic nor the diachronic aspect of this picture is predetermined according to pre-given patterns of rise and fall, unification and dispersion, and so on. All these matters are contingent on the details of the circumstances in which they are said to have occurred and become subject to narrative description. As I intend to discuss extensively in forthcoming work, this picture suggests that Islamic history should be understood as internally diverse and open to new possibilities without limits.

\section{Outcomes}

Understanding Islamic history as an open process has significant implications for considering the question of heritage. To begin, it indicates an investment away from Islamic universality. If there is no single Islamic history, then it follows that there can be no Islam that is available for transhistorical description. Instead, Islam is a conglomeration of thought and practice that is always under construction through the mediation of local factors. I believe it is important not to interpret this situation as implying a plurality of Islams. Thinking in terms of multiples rather than a singular Islam lets persist the problem of considering Islam a definable whole that stands apart from messy historical processes. It just makes room 
for multiple wholes rather than a single authoritative version. We need to reconsider the very nature of Islam as an object of discourse and understanding. From a historicizing perspective, Islam is best understood as a pluriform, entangled web, a singular that is irreducible to universal generalization in any dimension and needs unpacking according to analytical requirements of particular paradigms. I am suggesting that we retain Islam's nominal singularity while freeing it to signify in multiple, without any predetermined bounds. Whenever Islam is invoked as a term of intellectual and sociopolitical power, by proponents as well as opponents, it is in the singular rather than in multiples. But sociohistorical contextual observation tells us that this single Islam can refer to an extreme variety of things. On the side of "meaning," then, Islam is open-ended and ought to depend entirely on what we are able to observe relating to it in the world.

The perspective I am advocating is best explained through an example pertaining to heritage. Here I would like to concentrate on the great Friday mosque of Isfahan, Iran, which is suitable due to the great diversity of what it contains. This monument, a grand example of Islamic architecture, is also considered a repository of Iranian cultural identity and was recently designated a UNESCO World Heritage Site (UNESCO 2012). Considered synchronically as we can experience it today, the mosque is a meeting point between religious, national, and international discourses about heritage that are interdependent. From the vantage point of our historical location, the monument's status as an Islamic place of worship is inextricable from Iranian and international regimes pertaining to heritage. Visited as a tourist site by Iranians as well as foreigners in droves, it has been studied and restored most extensively by a team of Italian specialists who do not identify as Muslims (Galdieri 1972-1984). The mosque's contemporary significance as a historical repository is connected to modern national and global histories in which Islam holds particular kinds of meaning. The mosque's "heritage value" is conditioned by Islam as a "world religion," a category of modern provenance. Inasmuch as the mosque instantiates Islam, this is in a form determined by modern historiographical discourses. We go to it with expectations shaped by understandings of Islam that would have been alien to people alive centuries ago. Moreover, even today, preconceptions shaping the experience of the monument would differ greatly based on our own sociohistorical locations. The mosque is liable to have multiple modern interpretations, interlinked through the way its physicality is constituted and maintained under present regimes about the value of the type of object it is taken to be. 
The meaning we can make of the mosque changes if the observer is able to "read" its various features more deeply than what meets the eye upon a tourist excursion. It turns out to be a monument remarkable for having preserved more than a 1,000 years' worth of ongoing construction and modification (Grabar 1990). The site contains a large variety of building materials and architectural styles, together with epigraphy strewn throughout its expanse. Built forms and texts found in the monument signify the many different historical moments at which the monument's material configuration continued to transform over the centuries. For example, the southern section contains two impressive domes that reflect the Seljuk dynasty's investment in Isfahan as an imperial religiopolitical center during the eleventh-century CE (Hunarfar 1956, 75-81). The chamber of Öljeitü (d. 1316) with its heavily inscribed stucco mihrab contains the date $710 \mathrm{AH}(1310 \mathrm{CE})$ and is an effect of the Ilkhanid period. This site within the mosque reflects the public piety of a Mongol king who had recently converted to Islam (Hunarfar 1956, 116-120; Pfeiffer 1999). Extensive modifications and decoration undertaken during the Timurid period connect the mosque to Central Asia, the imperial center during the fourteenth and fifteenth centuries CE (Golombek and Wilbur 1988, 1:378-381). Additions from the Safavid period include epigraphy on a wall of the text of a public vow of repentance by the king Shah Tahmasp (d. 1576). We can read only half of this today since the bottom part broke away at some point and has not been found (Hunarfar 1956, 82).

These are some prominent examples from the trove of data pertaining to elites as well as the common people that is contained in the monument. The significant point for my purposes is that each cluster of evidence we can identify is traceable to a particular historical moment with its own sense of relevant Islamic heritage. Groups of people who inhabited the building in the eleventh century versus the fourteenth, sixteenth, or the nineteenth maintained particular imaginations of Islam and its past, present, and future. While all the evidence we see references Islam in the singular, the actual substance we can observe indicates a vast diversity of contents for the term. We can find many links between imaginations pertaining to different periods, as well as evidence for sedimentation of ideas over the course of time. But I am suggesting that we should resist reading different contexts as simple continuations of one another. Understanding the mosque as a fractured set of evidence manifests the monument as a conglomeration of interlinked items that cannot, however, be streamlined into a single story. 
I believe this perspective to be truer to the nature of the development of ideas and practices pertaining to Islam. Read in this way, the mosque approximates to the trove of narrative materials pertaining to the past that has amassed over the course of more than a millennium.

The density and variety of evidence available at the site of the Friday mosque in Isfahan makes it a case exceptional for its richness. However, I would like to suggest that principles regarding Islamic pasts that I have highlighted using it as an example are applicable more generally to materials and sites large and small. The ultimate point here is that heritage is an evaluative concept and is based on assessments of worth. Not all things from the past constitute heritage in all circumstances, and the ones that do differ between times and places. When assessing evidence pertaining to Islam, I suggest that we should begin with the presumption that Islamic understandings of the past are variable, both synchronically and diachronically. Traces at our disposal indicate a tremendous variety of ways of being and acting as Muslim. The diversity of meanings on display here has been inherent in Islamic discourses for all the contexts for which we have evidence. In tandem with these facts, Islamic valuations of heritage are also fundamentally diverse and changeable. As we can see in the case of the influence of the prestige of Italian restorers and modern organizations such as UNESCO, Islamic understandings need not be seen as exclusive or hermetic. Rather, the notion of heritage itself requires historicization in all contexts, which reveals investments held by us as well as people who created earlier material forms. I believe this perspective attunes us to pay the utmost attention to the particularities of the evidence we encounter while simultaneously avoiding reification and being mindful of shadows cast by interpretive paradigms old and new. Appreciating and creating heritage are closely related, if not synonymous, matters, something that is as true today as it was for Muslims of the past whose effects we scrutinize to create our narratives.

\section{Note}

1. For a translation of the ode in full see Meisami (1996). For general information about the poet see Anna Livia Beelaert, "Kaqani Servani," Encyclopaedia Iranica (http://www.iranicaonline.org/articles/kaqani-ser vani). Khaqani's ode stands in a long tradition of poetic reflection on the remains of the past in Persian and Arabic. For details, see Meisami (1996), Clinton (1976), Clinton (1977), and Ali (1968-1969). 
Acknowledgment This publication was made possible in part by a grant from the Carnegie Corporation of New York. The statements made and views expressed are solely the responsibility of the author.

\section{BiBLIOGRAPHY}

Ali, Saleh Ahmad El. 1968-1969. "Al-Mada'in and Its Surrounding Area in Arabic Literary Sources." Mesopotamia no. 3-4: 417-39.

Bashir, Shahzad. 2014. "On Islamic Time: Rethinking Chronology in the Historiography of Muslim Societies." History and Theory no. 53 (4): 519-544.

Bruno, Andrea, Giorgio Gullini, and Mariangiola Cavallero. 1966. "The Preservation and Restoration of Taq-i Kisra." Mesopotamia no. l (89-108), pls. xvii-xxv, figs. 35-59.

Clinton, Jerome. 1976. "The Madaen Qasida of Xaqani Sharvani I.” Edebiyat no. 1 (2): 153-170.

Clinton, Jerome. 1977. "The Madaen Qasida of Xaqani Sharvani II: Xaqani and alBuhturi." Edebiyat no. 2 (2): 191-206.

Galdieri, Eugenio. 1972-1984. Isfahan: Masgid-i Gum'a. 3 vols. Rome: IsMEO.

Golombek, Lisa, and Donald Wilbur 1988. The Timurid Architecture of Iran and Turan. 2 vols. Vol. 1. Princeton, NJ: Princeton University Press.

Grabar, Oleg. 1990. The Great Mosque of Isfahan. New York: New York University Press.

Hunarfar, Lutfullah. 1956. Ganjina-yi Asar-i Tarikhi-yi Isfahan. Isfahan, Iran: Kitabfurushi-yi Saqafi.

Khaqani. 1996. "Elegy on Mada'in." In Qasida Poetry in Islamic Asia and Africa: Eulogy's Bounty, Meaning's Abundance, edited by Stefan Sperl and Christopher Shackle. Leiden, Netherlands: Brill.

Meisami, Julie Scott. 1996. "Poetic Microcosms: The Persian Qasida to the End of the Twelfth Century." In Qasida Poetry in Islamic Asia and Africa: Classical Traditions and Modern Meanings, edited by Stefan Sperl and Christopher Shackle, 173-182. Leiden, Netherlands: Brill.

Pfeiffer, Judith. 1999. "Conversion Versions: Sultan Öljeytü's Conversion to Shi'ism (709/1309) in Muslim Narrative Sources.” Mongolian Studies no. 22: 35-67.

UNESCO. Masjed-e Jāmé of Isfahan. United Nations Educational, Scientific, and Cultural Organization (UNESCO), World Heritage Convention 2012 [accessed 25 April 2016]. Available from http://whc.unesco.org/en/list/ 1397.

Shahzad Bashir is Aga Khan Professor of Islamic Humanities at Brown University, USA. He specializes in intellectual and social history and is currently finishing a book entitled Islamic Pasts and Futures: Conceptual Explorations. 
Open Access This book is licensed under the terms of the Creative Commons Attribution 4.0 International License (http://creativecommons.org/licenses/ by $/ 4.0 /$ ), which permits use, sharing, adaptation, distribution and reproduction in any medium or format, as long as you give appropriate credit to the original author(s) and the source, provide a link to the Creative Commons license and indicate if changes were made.

The images or other third party material in this chapter are included in the chapter's Creative Commons license, unless indicated otherwise in a credit line to the material. If material is not included in the chapter's Creative Commons license and your intended use is not permitted by statutory regulation or exceeds the permitted use, you will need to obtain permission directly from the copyright holder. 